\title{
Preparation and Structure Studies of Monomeric and Dimeric [Bis(diphenylphosphino)pentane]tricarbonyliron(0)
}

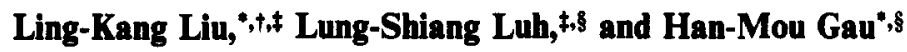 \\ Institute of Chemistry, Academia Sinica, Taipei, Taiwan 11529, ROC, Department of Chemistry, \\ National Taiwan University, Taipei, Taiwan 10767, ROC, and Department of Chemistry, National \\ Chung-Hsing University, Taichung, Taiwan 40227, ROC
}

Received December 13,1991

The $\left(\mathrm{CH}_{3}\right)_{3} \mathrm{NO}$ oxidative decarbonylation of (maleic acid) $\mathrm{Fe}(\mathrm{CO})_{4}$, followed by precipitation of trimethylammonium maleate in the presence of $\mathrm{Ph}_{2} \mathrm{P}\left(\mathrm{CH}_{2}\right)_{5} \mathrm{PPh}_{2}$ results in dimeric $\left[\left(\mathrm{Ph}_{2} \mathrm{P}\left(\mathrm{CH}_{2}\right)_{5} \mathrm{PPh}_{2}\right) \mathrm{Fe}(\mathrm{CO})_{3}\right]_{2}$ (1). The low-

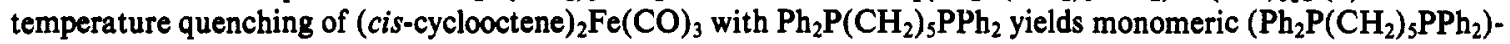
$\mathrm{Fe}(\mathrm{CO})_{3}(2)$. Both monomeric and dimeric forms have been studied by spectroscopic methods and X-ray diffraction. $\mathrm{X}$-ray crystallographic data for the title compounds are as follows: 1, monoclinic space group $C 2 / c, a=27.170$ (8) $\AA, b=14.458$ (2) $\AA, c=8.255$ (3) $\AA, \beta=102.88$ (2) $)^{\circ}, V=6991$ (3) $\AA^{3}, Z=4,2443$ data with $I_{0}>2.5 \sigma\left(I_{0}\right)$ refined to $R=0.054$ and $R_{w}=0.061 ; 2$, monoclinic, space group $C c, a=19.094$ (1) $\AA, b=10.455$ (1) $\AA, c=15.786$ (3) $\AA, \beta=114.89(3)^{\circ}, V=2858(2) \AA^{3}, Z=4,1723$ data with $I_{0}>2.5 \sigma\left(I_{0}\right)$ refined to $R=0.044$ and $R_{w}=0.051$. Monomeric 2 has a trigonal bipyramidal $\mathrm{Fe}(0)$ center with the chelating diphosphine occupying one axial and one equatorial site, corresponding to a cis form. The structure of 1 reveals that the two trigonal bipyramidal $\mathrm{Fe}(0)$ centers are bridged by two $\mathrm{Ph}_{2} \mathrm{P}\left(\mathrm{CH}_{2}\right)_{3} \mathrm{PPh}_{2}$ ligands and each $\mathrm{Fe}(0)$ center has two $\mathrm{P}$ donors diaxially coordinated, corresponding to a trans form.

\section{Introduction}

The established methods of synthesizing (diphosphine) $\mathrm{Fe}(\mathrm{CO})_{3}$ derivatives generally involve the direct reaction of a diphosphine with iron carbonyls under various conditions. ${ }^{1-13}$ The treatment of iron carbonyls with diphosphines such as dppm, dppe, or dppp at elevated temperatures or under UV irradiation leads to the formation of both $(\mathrm{P} \sim \mathrm{P}) \mathrm{Fe}(\mathrm{CO})_{3}$ and $(\mathrm{OC})_{4} \mathrm{Fe}(\mu-\mathrm{P} \sim \mathrm{P}) \mathrm{Fe}(\mathrm{CO})_{4}$ $(\mathrm{P} \sim \mathrm{P}=\mathrm{dppm}, \mathrm{dppe}, \mathrm{dppp})$. The yields are variable, and generally the separation of diphosphine, chelated and bridging products is tedious.

Increasing the chain length of a diphosphine inevitably changes the chelate ring size of the corresponding $(\mathrm{P} \sim \mathrm{P}) \mathrm{Fe}(\mathrm{CO})_{3}$ derivatives. For $\mathrm{P} \sim \mathrm{P}=$ dppm and dppe, ${ }^{14,15}$ the bonding geometry of $(\mathrm{P} \sim \mathrm{P}) \mathrm{Fe}(\mathrm{CO})_{3}$ conforms to a distorted square pyramid with the two $P$ donors being dibasal and cis. For $P \sim P=d p p p$ and $\mathrm{dppf},{ }^{16,17}$ the coordination geometry of $(\mathrm{P} \sim \mathrm{P}) \mathrm{Fe}(\mathrm{CO})_{3}$ can be

- To whom correspondence should be addressed

+ Academia Sinica.

National Taiwan University.

National Chung-Hsing University.

(1) King, R. B.; Eggers, C. A. Inorg. Chim. Acta 1968, 2, 33.

(2) Cullen, W. R.; Harbourn, D. A. Can. J. Chem. 1969, 47, 3371.

(3) Collman, J. P.; Komoto, R. G.; Siegl, W. O. J. Am. Chem. Soc. 1972. 95, 2389 .

(4) Carroll, W. E.; Deeney, F. A.; Delaney, J. A.; Lalor, F. J. J. Chem. Soc., Dalton Trans. 1973, 718.

(5) Fenske, D. Chem. Ber. 1979, 112, 363.

(6) Manuel, T. A. Inorg. Chem. 1963, 2, 854

(7) Akhtar, M.; Ellis, P. D.; Macdiarmid, A. G.; Odom, J. D. Inorg. Chem. 1972, $i 1,2917$.

(8) Allison, D. A.; Clardy, J.; Verkade, J. G. Inorg. Chem. 1972, 11, 2804.

(9) Langford, G. R.; Akhtar, M.; Ellis, P. D.; Macdiarmid, A. G.; Odom, J. D. Inorg. Chem. 1975, 14, 2937.

(10) Alper, H.; Partis, R. A. J. Organomet. Chem. 1972, 44, 371.

(11) Claucas, J. A.; Dawson, R. H.; Dolby, P. A.; Harding, M. M.; Peason, K.; Smith, A. K. J. Organomet. Chem. 1986, 311, 153.

(12) Brunet, J. J.; Kindela, F. B.; Neibecker, D. J. Organomet. Chem. 1989, $368,209$.

(13) Hor, T. S. A.; Phang, L. T. J. Organomet. Chem. 1990, 381, 121

(14) Cotton, F. A.; Hardcastle, K. I.; Rusholme, G. A. J. Coord. Chem. 1973, 2, 217 .

(15) Battaglia, L. P.; Nardelli, M.; Delledonne, D.; Pelizzi, C.; Predieri, G.; Chiusoli, G. P. J. Organomet. Chem. 1987, 330, 101

(16) Luh, L.-S. Masters Thesis, Department of Chemistry, National ChungHsing University, Taichung, Taiwan, 1990. described as trigonal bipyramidal with one of the $P$ donors being in the axial position and the other equatorial. For $\mathbf{P} \sim \mathbf{P}=$ $\mathrm{Ph}_{2} \mathrm{P}\left(\mathrm{CH}_{2}\right)_{5} \mathrm{PPh}_{2}$, abbreviated as dppt, we report here the successful synthesis of both dimeric $\left[(\mathrm{dppt}) \mathrm{Fe}(\mathrm{CO})_{3}\right]_{2}(1)$ and monomeric (dppt) $\mathrm{Fe}(\mathrm{CO})_{3}(2)$ in very good yields via routes not previously reported. We also present the X-ray structure determinations of 1 and 2.

\section{Experimental Section}

All manipulations were performed under an atmosphere of prepurified nitrogen with standard Schlenk techniques, and all solvents were distilled from an appropriate drying agent. ${ }^{18}$ Infrared spectra were recorded in $\mathrm{CH}_{2} \mathrm{Cl}_{2}$ using $\mathrm{CaF}_{2}$ optics on a Perkin-Elmer 882 spectrophotometer. The ${ }^{31} \mathrm{P}\left\{{ }^{1} \mathrm{H}\right\}$ NMR spectra were obtained on a Bruker MSL 200 spectrometer using $85 \% \mathrm{H}_{3} \mathrm{PO}_{4}$ as an external standard. (MA) $\mathrm{Fe}(\mathrm{CO})_{4}, \mathrm{MA}=$ maleic acid, and $(\mathrm{COE})_{2} \mathrm{Fe}(\mathrm{CO})_{3}, \mathrm{COE}=c i s-c y-$ clooctene, were prepared according to the literature procedures. ${ }^{19,20}$ Other reagents were obtained from commercial sources, e.g. Aldrich and Merck, and used without further purification.

Preparation of $\left[(\mathrm{dppt}) \mathrm{Fe}(\mathrm{CO})_{3}\right]_{2}$ (1). (MA) $\mathrm{Fe}(\mathrm{CO})_{4}(284 \mathrm{mg}, 1$ $\mathrm{mmol})$ and dppt $(440 \mathrm{mg}, 1 \mathrm{mmol})$ were dissolved in THF $(50 \mathrm{~mL})$, and the solutions were stirred for $30 \mathrm{~min}$ at $0^{\circ} \mathrm{C}$. $\left(\mathrm{CH}_{3}\right)_{3} \mathrm{NO} \cdot 2 \mathrm{H}_{2} \mathrm{O}(167 \mathrm{mg}$, $1.5 \mathrm{mmol})$ in $\mathrm{CH}_{3} \mathrm{OH}(1 \mathrm{~mL}) / \mathrm{THF}(15 \mathrm{~mL})$ was added dropwise to the solution during a period of $2 \mathrm{~h}$. The color of the solution changed from yellow to dark-brown. The solution was then refluxed at $70^{\circ} \mathrm{C}$ for $2 \mathrm{~h}$ before filtration and evaporation to dryness under vacuum. The resulting yellow crystals were purified by chromatography $\left(\mathrm{Al}_{2} \mathrm{O}_{3}\right.$, eluting with $\mathrm{CH}_{2} \mathrm{Cl}_{2} / n$-hexane) and recrystallization $\left(\mathrm{CH}_{2} \mathrm{Cl}_{2} / n\right.$-hexane) to give 1 $(527 \mathrm{mg}, 45.4 \%)$ as a yellowish compound. Crystals suitable for $\mathrm{X}$-ray diffraction were grown from $\mathrm{CH}_{2} \mathrm{Cl}_{2} / n$-hexane by a slow evaporation method: ${ }^{31} \mathrm{P}\left\{{ }^{1} \mathrm{H}\right\}$ NMR $\left(\mathrm{CDCl}_{3}\right) \delta 75.53$ (s); IR $\left(\mathrm{CH}_{2} \mathrm{Cl}_{2}\right) \nu_{\mathrm{CO}} 1877$ $\mathrm{cm}^{-1}$; mp 208-210 ${ }^{\circ} \mathrm{C} \mathrm{dec}$; MS $(\mathrm{m} / z)$ for $\mathrm{C}_{64} \mathrm{H}_{60} \mathrm{Fe}_{2} \mathrm{O}_{6} \mathrm{P}_{4}, 1415\left(\mathrm{M}^{+}\right.$, parent ion). Anal. Calcd for $\mathrm{C}_{67} \mathrm{H}_{66} \mathrm{Cl}_{6} \mathrm{Fe}_{2} \mathrm{O}_{6} \mathrm{P}_{4}$ : C, 56.82; $\mathrm{H}, 4.66$. Found: C, 57.67; H, 5.03.

(17) Liu, L.-K.; Yeh, S. K.; Lin, C. C. Bull. Inst. Chem. Acad. Sin. 1988, 35,45 .

(18) Perrin, D. D.; Armarego, W. L. F.; Perrin, D. R. Purification of Laboratory Chemicals; Pergamon Press: Oxford, England, 1981.

(19) Weiss, E.; Stark, K.; Lancaster, J. E.; Murdoch, H. D. Helv. Chem. Acta 1963, 46, 288.

(20) Fleckner, H.; Grevels, F.-W.; Hess, D. J. Am. Chem. Soc. 1984, 106, 2027. 
Table I. Crystallographic Data and Refinement Details for $\left[(\mathrm{dppt}) \mathrm{Fe}(\mathrm{CO})_{3}\right]_{2} \cdot 3 \mathrm{CH}_{2} \mathrm{Cl}_{2}$ (1) and (dppt) $\mathrm{Fe}(\mathrm{CO})_{3}(2)$

\begin{tabular}{lll}
\hline & \multicolumn{1}{c}{1} & \multicolumn{1}{c}{2} \\
\hline empirical formula & $\mathrm{C}_{67} \mathrm{H}_{66} \mathrm{Cl}_{6} \mathrm{Fe}_{2} \mathrm{O}_{6} \mathrm{P}_{4}$ & $\mathrm{C}_{32} \mathrm{H}_{30} \mathrm{FeO}_{3} \mathrm{P}_{2}$ \\
fw & 1415.56 & 580.38 \\
space group & $C 2 / c$ & $C c$ \\
$a, \AA$ & $27.170(8)$ & $19.094(1)$ \\
$b, \AA$ & $14.458(2)$ & $10.455(1)$ \\
$c, \AA$ & $8.255(3)$ & $15.786(3)$ \\
$\beta, \mathrm{deg}$ & $102.88(2)$ & $114.89(3)$ \\
$V, \AA^{3}$ & $6991(3)$ & $2858(2)$ \\
$Z$ & 4 & 4 \\
$T, \mathrm{~K}$ & 298 & 298 \\
$\lambda(\mathrm{Mo} \mathrm{K} \alpha), \AA$ & 0.7093 & 0.7093 \\
$D_{\text {calc, }} \mathrm{cm}^{-3}$ & 1.345 & 1.349 \\
$\mu, \mathrm{mm}^{-1}$ & 0.78 & 0.67 \\
abs corr & yes & yes \\
transm factors & $0.948-1.000$ & $0.889-1.000$ \\
$R\left(F_{\mathrm{o}}\right)^{a}$ & 0.054 & 0.044 \\
$R_{\mathrm{w}}\left(F_{\mathrm{o}}\right)^{a}$ & 0.061 & 0.051 \\
${ }^{a} R\left(F_{\mathrm{o}}\right)=\sum\left(F_{\mathrm{o}}-F_{\mathrm{c}}\right) / \Sigma F_{\mathrm{o}} ; R_{\mathrm{w}}\left(F_{\mathrm{o}}\right)=\left[\sum w\left(F_{\mathrm{o}}-F_{\mathrm{c}}\right)^{2} / \sum w F_{\mathrm{o}}{ }^{2}\right]^{1 / 2}$.
\end{tabular}

Structure Analysis of [(dppt) $\left.\mathrm{Fe}(\mathrm{CO})_{3}\right]_{2} \cdot \mathbf{C C H}_{2} \mathrm{Cl}_{2}(1)$. A single crystal of ca. $0.47 \times 0.31 \times 0.34 \mathrm{~mm}$ was used for the data collection. Intensity measurements were performed on a Nonius CAD-4 automated diffractometer using graphite-monochromated Mo $\mathrm{K} \alpha$ radiation. A total of 25 high-angle reflections, $18.98 \leq 2 \theta \leq 36.54^{\circ}$, were used in a least-squares fit to obtain accurate cell constants. Diffraction intensities were measured up to $2 \theta \leq 45^{\circ}$ using the $\theta / 2 \theta$ scan technique, with background counts made for half the total scan time on each side of the peak. Three standard reflections, remeasured every $1 \mathrm{~h}$, showed no significant decrease in intensity during data collection. Of the 4568 unique reflections measured, 2443 were classed as observed $\left[I_{0}>2.5 \sigma\left(I_{0}\right)\right]$ and were used for solution and structure refinement. Data were corrected for Lorentz-polarization factors. An empirical absorption correction based on a series of $\psi$ scans was applied to the data. The structure was solved by direct methods ${ }^{21}$ and refined by a full-matrix least-squares routine ${ }^{22}$ with anisotropic thermal parameters for all non-hydrogen atoms (weight $=1 /\left[\sigma\left(F_{0}\right)^{2}+\right.$ $\left.0.0001\left(F_{0}\right)^{2}\right], \sigma\left(F_{0}\right)$ from counting statistics). All of the hydrogen atoms were placed isotropically at their calculated positions $(\mathrm{C}-\mathrm{H}=1.00 \AA)$ and fixed in the calculations. Atomic scattering factor curves $f_{0}, \Delta f^{\prime}$, and $\Delta f^{\prime}$ of $\mathrm{Fe}, \mathrm{P}, \mathrm{O}$, and $\mathrm{C}$ and $f_{0}$ of $\mathrm{H}$ were taken from ref 23. Final refinement converged to $R=0.054$ and $R_{\mathrm{w}}=0.061$. For a summary of crystal data and refinement details, see Table I. Selected bond distances and angles are given in the caption of Figure 1 , and final atomic fractional coordinates, in Table II.

Preparation of (dppt)Fe(CO) $)_{3}$ (2). A solution of $(\mathrm{COE})_{2} \mathrm{Fe}(\mathrm{CO})_{3}$ (360 mg, $1 \mathrm{mmol})$ in THF $(30 \mathrm{~mL})$ was stirred for $10 \mathrm{~min}$ at $-60^{\circ} \mathrm{C}$ before adding dropwise dppt ( $440 \mathrm{mg}, 1 \mathrm{mmol})$ in THF (15 mL). After the temperature was kept at $-60^{\circ} \mathrm{C}$ for an additional $2 \mathrm{~h}$, the solution was allowed to warm to room temperature. The solution was then filtered, and the filtrate was evaporated to dryness under vacuum giving a yellow solid. The solid was washed with $n$-hexane $(3 \times 30 \mathrm{~mL})$ to give $2(541$ $\mathrm{mg}, 93.1 \%$ ) as a yellow powder. Crystals suitable for X-ray diffraction were grown by slow evaporation from $\mathrm{CH}_{2} \mathrm{Cl}_{2} / n$-hexane: ${ }^{31} \mathrm{P}\{1 \mathrm{H}\} \mathrm{NMR}$ $\left(\mathrm{CDCl}_{3}\right) \delta 55.48$ (s); IR $\left(\mathrm{CH}_{2} \mathrm{Cl}_{2}\right) \nu_{\mathrm{CO}} 1983$ (s), 1912 (s), 1883 (vs) cm-1; mp $155-158{ }^{\circ} \mathrm{C}$; $\mathrm{MS}(m / z)$ for $\mathrm{C}_{32} \mathrm{H}_{30} \mathrm{FeO}_{3} \mathrm{P}_{2}, 580\left(\mathrm{M}^{+}\right.$, parent ion). Anal. Calcd for $\mathrm{C}_{32} \mathrm{H}_{30} \mathrm{FeO}_{3} \mathrm{P}_{2}: \mathrm{C}, 66.22 ; \mathrm{H}, 5.21$. Found: $\mathrm{C}, 66.20$; H, 4.86 .

Structure Analysis of (dppt)Fe(CO) 3 (2). A crystal of ca. $0.44 \times 0.36$ $\times 0.22 \mathrm{~mm}$ was used for the data collection. Intensity data were collected in a fashion similar to that for 1 . Of 1957 unique reflections measured, 1723 were classed as observed $\left[I_{0}>2.5 \sigma\left(I_{0}\right)\right]$ and were used for solution

(21) Main, P. In Crystallographic Computing 3: Data Collection, Structure Determination, Proteins and Databases; Sheldrick, G. M., Krueger, C., Goddard, R., Eds.; Clarendon Press: Oxford, England, 1985; pp 206215.

(22) (a) Gabe, E. J.; Le Page, Y.; White, P. S.; Lee, F. L. Acta Crystallogr. 1987, 43A, S294. (b) Gabe, E. J.; Le Page, Y.: Lee, F. L. In Crystallographic Computing 3: Data Collection, Structure Determination, Proteins and Databases; Sheldrick, G. M., Krueger, C., Goddard, R., Eds.; Clarendon Press: Oxford, England, 1985; pp 167-174.

(23) Ibers, J. A.; Hamilton, W. C. International Tables for X-ray Crystallography; Kynoch: Birmingham, England, 1974 (current distributor D. Reidel, Dordrecht, The Netherlands); Vol. IV, Tables 2.2A, 2.3.1D.

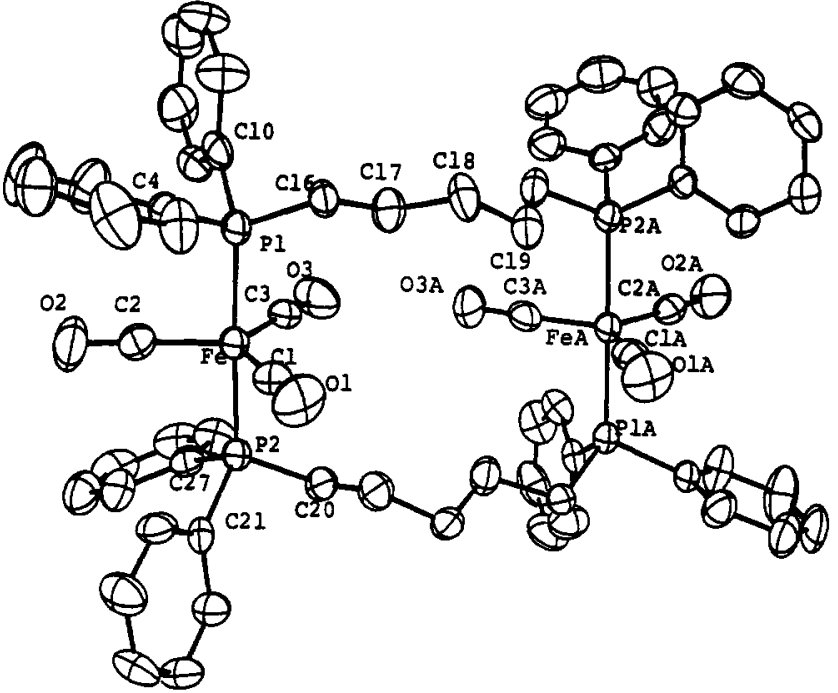

Figure 1. ORTEP diagram with atom-numbering scheme for 1 with thermal ellipsoids scaled to enclose $50 \%$ of the electron density. The $\mathrm{H}$ atoms are omitted for clarity. Selected bond lengths $(\AA)$ and angles (deg): $\mathrm{Fe}-$ $\mathrm{P}(1)=2.206(2), \mathrm{Fe}-\mathrm{P}(2)=2.216(2), \mathrm{Fe}-\mathrm{C}(1)=1.769(9), \mathrm{Fe}-\mathrm{C}(2)$ $=1.762(9), \mathrm{Fe}-\mathrm{C}(3)=1.763(9) ; \mathrm{P}(1)-\mathrm{Fe}-\mathrm{P}(2)=177.78(9), \mathrm{P}(1)-$ $\mathrm{Fe}-\mathrm{C}(1)=90.8(3), \mathrm{P}(1)-\mathrm{Fe}-\mathrm{C}(2)=87.6(3), \mathrm{P}(1)-\mathrm{Fe}-\mathrm{C}(3)=90.3$ (3), $\mathrm{P}(2)-\mathrm{Fe}-\mathrm{C}(1)=87.6(3), \mathrm{P}(2)-\mathrm{Fe}-\mathrm{C}(2)=91.9(3), \mathrm{P}(2)-\mathrm{Fe}-\mathrm{C}(3)$ $=91.8$ (3), $\mathrm{C}(1)-\mathrm{Fe}-\mathrm{C}(2)=122.5(4), \mathrm{C}(1)-\mathrm{Fe}-\mathrm{C}(3)=117.9$ (4), $\mathrm{C}(2)-\mathrm{Fe}-\mathrm{C}(3)=119.6(4)$.

and structure refinement. The structure was solved by direct methods. Final refinement converged to $R=0.044$ and $R_{\mathrm{w}}=0.051$. For a summary of crystal data and refinement details, see Table $I$. Selected bond distances and angles are given in the caption of Figure 2, and final fractional atomic coordinates, in Table III.

Monitoring of Changes of 2 under Heating. Compound 2 was dissolved in THF ( $50 \mathrm{~mL})$ and refluxed under nitrogen for 2 days. The IR $v_{\mathrm{CO}}$ pattern was monitored every $4 \mathrm{~h}$, revealing no significant changes throughout the period. The ${ }^{31} \mathrm{P}\left\{{ }^{1} \mathrm{H}\right\}$ NMR spectra of reaction mixtures after 2 days exhibited the presence of paramagnetic species but not 1 .

\section{Results and Discussion}

Synthesis. Two different routes have been employed for the dppt ligation onto a $\mathrm{Fe}(\mathrm{CO})_{3}$ moiety (Scheme I). The first proceeds by an oxidative decarbonylation of (MA) $\mathrm{Fe}(\mathrm{CO})_{4}$ by $\mathrm{Me}_{3} \mathrm{NO}$ followed by precipitation of trimethylammonium maleate in the presence of $\mathrm{Ph}_{2} \mathrm{P}\left(\mathrm{CH}_{2}\right)_{5} \mathrm{PPh}_{2}$, dppt. The initial stage is the $\mathrm{O}$ atom transfer from $\mathrm{Me}_{3} \mathrm{NO}$ to a $\mathrm{CO}$ ligand producing gaseous $\mathrm{CO}_{2}$ and $\mathrm{NMe}_{3}$ with $\mathrm{NMe}_{3}$ temporarily occupying the vacated site. Then during the dppt chelation stage in refluxing THF, the leaving ligand MA reacts with $\mathrm{NMe}_{3}$ to form a salt $\left(\mathrm{HNMe}_{3}\right)^{+} \mathrm{MA}^{-}$. The second is a low-temperature reaction of $(\mathrm{COE})_{2} \mathrm{Fe}(\mathrm{CO})_{3}$ with dppt. The oxidative decarbonylation method requires a much higher temperature than the ligand substitution of $(\mathrm{COE})_{2} \mathrm{Fe}(\mathrm{CO})_{3}$. The two methods result in different products. The high-temperature route produces 1 in a $45.4 \%$ yield whereas the low-temperature route gives 2 in a virtually quantitative yield.

Spectroscopy. Both 1 and 2 have been characterized with ${ }^{31} \mathrm{P}$ \{ $\left.{ }^{\prime} \mathrm{H}\right\} \mathrm{NMR}, \mathrm{IR}, \mathrm{mp}, \mathrm{EA}, \mathrm{MS}$, and X-ray structure analysis. 1 exhibits only one $\nu_{\mathrm{CO}}$ absorption and 2 exhibits three $\nu_{\mathrm{CO}}$ absorptions in the IR spectra. This suggests that there are completely different coordination arrangements around $\mathrm{Fe}(0)$ in 1 and 2. With one $\nu$ co band, 1 is expected to have two $P$ atoms coordinated diaxially at trans positions around a tbp $\mathrm{Fe}(0)$ center, whereas, with three $\nu_{\mathrm{CO}}$ bands, 2 is expected to have one $\mathbf{P}$ atom axial and the other $\mathbf{P}$ atom equatorial. ${ }^{24}$ In $\mathrm{d}^{8}$ complexes, $\pi$ accepting ligands will prefer the equatorial position. As a less

(24) Collman, J. P.; Hegedus, L. S. Principles and Applications of Organotransition Metal Chemistry; University Science Books: Mill Valley; CA, 1980; pp 81-89. 
Table II. Final Atomic Fractional Coordinates and Equivalent Isotropic Displacement Coefficients $\left(\AA^{2}\right)$ for $\left[(\mathrm{dppt}) \mathrm{Fe}(\mathrm{CO})_{3}\right]_{2} \cdot 3 \mathrm{CH}_{2} \mathrm{Cl}_{2}(\mathrm{1})$

\begin{tabular}{|c|c|c|c|c|}
\hline atom & $x$ & $y$ & $z$ & $B_{\text {iso }}{ }^{a}$ \\
\hline $\mathrm{Fe}$ & $0.12367(4)$ & $0.25753(8)$ & $0.18543(6)$ & $2.73(5)$ \\
\hline$P(1)$ & $0.15924(7)$ & $0.26594(14)$ & $0.30632(12)$ & $2.78(10)$ \\
\hline$P(2)$ & $0.08566(7)$ & $0.24550(15)$ & $0.06507(11)$ & $2.78(10)$ \\
\hline $\mathrm{Cl}(1)$ & $0.6180(3)$ & $0.2874(6)$ & $0.1272(5)$ & $23.55(69)$ \\
\hline $\mathrm{Cl}(2)$ & 0.5964 (3) & $0.1720(7)$ & $0.2271(5)$ & $29.95(82)$ \\
\hline $\mathrm{Cl}(3)$ & $0.4777(4)$ & $0.3980(5)$ & $0.1779(4)$ & $28.38(81)$ \\
\hline$O(1)$ & $0.1103(3)$ & $0.0574(4)$ & $0.1955(4)$ & $6.1(4)$ \\
\hline$O(2)$ & $0.0493(2)$ & $0.3904(5)$ & $0.2153(4)$ & $5.8(4)$ \\
\hline$O(3)$ & $0.2177(2)$ & $0.3228(5)$ & 0.1502 (4) & $6.2(4)$ \\
\hline$C(1)$ & $0.1158(3)$ & $0.1366(6)$ & $0.1925(5)$ & $3.8(5)$ \\
\hline$C(2)$ & $0.0785(3)$ & $0.3376(6)$ & $0.2020(4)$ & $3.6(4)$ \\
\hline$C(3)$ & $0.1797(3)$ & $0.2979(6)$ & $0.1630(5)$ & $3.6(4)$ \\
\hline$C(4)$ & $0.2091(3)$ & $0.1818(5)$ & $0.3438(4)$ & $2.7(4)$ \\
\hline$C(5)$ & $0.2312(3)$ & $0.1279(6)$ & $0.2968(4)$ & $3.5(4)$ \\
\hline$C(6)$ & $0.2698(3)$ & $0.0671(6)$ & $0.3259(5)$ & $4.7(5)$ \\
\hline$C(7)$ & $0.2873(3)$ & $0.0596(6)$ & $0.4023(5)$ & $4.3(4)$ \\
\hline$C(8)$ & $0.2661(3)$ & $0.1103(6)$ & $0.4496(5)$ & $4.2(5)$ \\
\hline$C(9)$ & $0.2280(3)$ & $0.1717(5)$ & $0.4219(5)$ & $3.5(4)$ \\
\hline$C(10)$ & $0.1909(3)$ & $0.3763(5)$ & $0.3361(4)$ & $3.2(4)$ \\
\hline$C(11)$ & $0.1635(3)$ & $0.4529(6)$ & $0.3492(5)$ & $4.3(4)$ \\
\hline$C(12)$ & $0.1874(4)$ & $0.5362(6)$ & $0.3713(5)$ & $5.3(6)$ \\
\hline$C(13)$ & $0.2385(4)$ & $0.5437(7)$ & $0.3798(6)$ & $5.6(6)$ \\
\hline$C(14)$ & $0.2661(4)$ & $0.4696(7)$ & $0.3653(6)$ & $5.0(5)$ \\
\hline C(15) & $0.2427(3)$ & $0.3875(6)$ & $0.3443(5)$ & $4.0(4)$ \\
\hline$C(16)$ & $0.1159(3)$ & $0.2539(6)$ & $0.3694(4)$ & $3.4(4)$ \\
\hline$C(17)$ & $0.0881(3)$ & $0.1608(6)$ & $0.3606(5)$ & $3.9(4)$ \\
\hline$C(18)$ & 0.0559 & $0.1454(6)$ & $0.4186(5)$ & $4.1(4)$ \\
\hline$C(19)$ & $-0.0119(3)$ & $0.2106(5)$ & $0.0898(5)$ & $3.8(4)$ \\
\hline$C(20)$ & $0.0272(3)$ & $0.1765(5)$ & $0.0456(4)$ & $3.2(4)$ \\
\hline$C(21)$ & $0.1241(3)$ & $0.1881(5)$ & $0.0081(4)$ & $3.0(4)$ \\
\hline$C(22)$ & $0.1562(3)$ & $0.2399(6)$ & $-0.0234(5)$ & $4.9(5)$ \\
\hline$C(23)$ & $0.1876(4)$ & $0.1970(7)$ & $-0.0644(6)$ & $6.4(6)$ \\
\hline$C(24)$ & $0.1864(4)$ & $0.1045(8)$ & $-0.0741(6)$ & $5.5(6)$ \\
\hline$C(25)$ & $0.1556(4)$ & $0.0520(7)$ & $-0.0404(6)$ & $6.0(6)$ \\
\hline$C(26)$ & $0.1243(3)$ & $0.0932(6)$ & $0.0000(5)$ & $4.5(5)$ \\
\hline$C(27)$ & $0.0674(3)$ & $0.3515(5)$ & $0.0113(5)$ & $3.3(4)$ \\
\hline$C(28)$ & $0.0406(4)$ & $0.3460(6)$ & $-0.0638(6)$ & $5.1(5)$ \\
\hline$C(29)$ & $0.0295(4)$ & $0.4273(8)$ & $-0.1049(5)$ & $5.7(6)$ \\
\hline$C(30)$ & $0.0434(4)$ & $0.5102(7)$ & $-0.0749(7)$ & $5.4(6)$ \\
\hline$C(31)$ & $0.0696(4)$ & $0.5172(6)$ & $-0.0019(6)$ & $5.1(6)$ \\
\hline$C(32)$ & $0.0816(3)$ & $0.4383(6)$ & $0.0408(5)$ & $3.9(4)$ \\
\hline$C(33)$ & $0.6362(7)$ & $0.2817(24)$ & $0.2189(10)$ & $22.9(26)$ \\
\hline$C(34)$ & 0.5000 & $0.4623(19)$ & 0.2500 & $19.2(27)$ \\
\hline
\end{tabular}

$\pi$-accepting ligand than $\mathrm{CO}$, a phosphine is generally found to preferentially occupy the axial position. ${ }^{25}$ Accordingly, one phosphine moiety of dppt coordinates to the axial site of a tbp $\mathrm{Fe}(0)$. Chelation then brings the second phosphine moiety cis to the first one, forming a chelate structure 2. However, there is also the possibility of dppt coordinating in bridging or unidentate modes for which the two phosphine moieties from two different dppt's would coordinate to a $\mathrm{Fe}(\mathrm{CO})_{3}$ unit diaxially. Such species would exhibit only one $\nu_{\text {co }}$ infrared stretching frequency.

The ${ }^{31} P$ NMR spectrum also suggests that 1 contains two axial $\mathrm{P}$ donors whereas 2 contains two cis $\mathbf{P}$ donors since diaxial $-\mathrm{P}_{2^{-}}$ $\mathrm{Fe}(\mathrm{CO})_{3}(\mathrm{P}=$ a phosphine ligand) generally exhibits a lower field chemical shift than cis- $\mathrm{P}_{2} \mathrm{Fe}(\mathrm{CO})_{3}$, e.g. $\left(\mathrm{Ph}_{2} \mathrm{PMe}\right)_{2} \mathrm{Fe}(\mathrm{CO})_{3}$ at $\delta 64.7$ (in $\left.\mathrm{CDCl}_{3}\right)^{26}$ and (dppb) Fe(CO) ${ }_{3}$ at $\delta 61.7$ (in acetone$\mathrm{d}_{6}$ ), which would be correlated to a peak at ca. $\delta 57$ in $\mathrm{CDCl}_{3} .{ }^{16}$ For 1 the resonance of the $P$ donor atoms appears at $\delta 75.53$, as compared to the higher field resonance of 2 at $\delta 55.48$. It is reasonable to conclude that 1 is likely in a diaxial form and 2 is likely in a cis form.

Although the two cis $\mathbf{P}$ donor atoms in 2 have different environments, the ${ }^{31} \mathrm{P}\left\{{ }^{1} \mathrm{H}\right\}$ NMR spectrum of 2 exhibits only one

(25) (a) Huheey, J. E. Inorganic Chemistry; Harper \& Row Publishers: New York, 1983; pp 471-484. (b) Rossi, A. R.; Hoffmann, R. Inorg. Chem. 1975, 14, 365.

(26) Albers, M. O.; Colville, N. J.; Ashworth, T. V.; Singleton, E. J. Organomet. Chem. 1981, 217, 385.

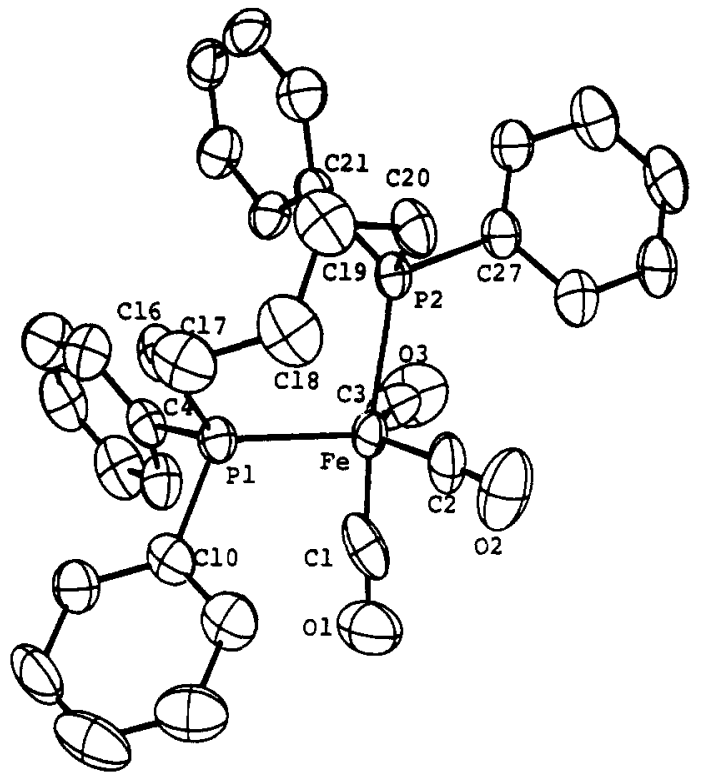

Figure 2. ORTEP diagram with atom-numbering scheme for 2 with thermal ellipsoids scaled to enclose $50 \%$ of the electron density. The $\mathrm{H}$ atoms are omitted for clarity. Selected bond lengths $(\AA)$ and angles (deg): $\mathrm{Fe}-$ $\mathrm{P}(1)=2.250$ (3), Fe-P(2) = $2.256(3), \mathrm{Fe}-\mathrm{C}(1)=1.657$ (14), $\mathrm{Fe}-\mathrm{C}(2)$ $=1.727(11), \mathrm{Fe}-\mathrm{C}(3)=1.763(12) ; \mathrm{P}(1)-\mathrm{Fe}-\mathrm{P}(2)=97.05$ (12), $\mathrm{P}(1)-$ $\mathrm{Fe}-\mathrm{C}(1)=90.8(4), \mathrm{P}(1)-\mathrm{Fe}-\mathrm{C}(2)=114.6(4), \mathrm{P}(1)-\mathrm{Fe}-\mathrm{C}(3)=117.0$ (4), $\mathrm{P}(2)-\mathrm{Fe}-\mathrm{C}(1)=171.8$ (4), $\mathrm{P}(2)-\mathrm{Fe}-\mathrm{C}(2)=87.9(4), \mathrm{P}(2)-\mathrm{Fe}-$ $\mathrm{C}(3)=87.5(4), \mathrm{C}(1)-\mathrm{Fe}-\mathrm{C}(2)=90.9(6), \mathrm{C}(1)-\mathrm{Fe}-\mathrm{C}(3)=86.9(5)$, $\mathrm{C}(2)-\mathrm{Fe}-\mathrm{C}(3)=128.4(5)$.

single peak at $298 \mathrm{~K}$ at an apparently fluxional average on the NMR time scale, similar to other cis- $\mathrm{P}_{2} \mathrm{Fe}(\mathrm{CO})_{3}$ complexes whose ${ }^{13} \mathrm{C}$ NMR spectra were reported to display only one resonance down to e.g. $-70^{\circ} \mathrm{C}$ for $\left(\mathrm{Me}_{2} \mathrm{PCF}_{2} \mathrm{CH}_{2} \mathrm{PMe}_{2}\right) \mathrm{Fe}(\mathrm{CO})_{3},-80^{\circ} \mathrm{C}$ for dpppFe $(\mathrm{CO})_{3}$, and $-140^{\circ} \mathrm{C}$ for $\left[0-\mathrm{C}_{6} \mathrm{H}_{4}(\mathrm{AsMe})_{2}\right] \mathrm{Fe}(\mathrm{CO})_{3} .^{7,9}$ The low-temperature ${ }^{13} \mathrm{C}$ or ${ }^{31} \mathrm{P}\left\{{ }^{1} \mathrm{H}\right\}$ NMR data of 2 were not measured.

Structure. Figure 1 shows the X-ray structure of 1 , in which the dimeric trigonal-bipyramidal $\mathrm{Fe}(0)$ centers have two dppt bridges and the two $P$ atoms coordinated to the same $\mathrm{Fe}(0)$ center are trans. The six atoms constituting of $\mathrm{Fe}, \mathrm{P}(1), \mathrm{P}(2), \mathrm{Fe}(\mathrm{a})$, $\mathrm{P}(1 \mathrm{a})$, and $\mathrm{P}(2 \mathrm{a})$ are nearly coplanar within \pm 0.164 (3) $\AA . A$ crystallographically required 2-fold axis passes through the center of gravity and is perpendicular to this plane. With $Z=4$ in the space group $C 2 / c$, only half of the dimeric 1 is crystallographically independent. As three $\mathrm{CH}_{2} \mathrm{Cl}_{2}$ solvate molecules are associated with one dimeric 1 , one and one-half $\mathrm{CH}_{2} \mathrm{Cl}_{2}$ molecules are independent. The crystallographically independent half $\mathrm{CH}_{2}$. $\mathrm{Cl}_{2}$ has its $\mathrm{C}$ atom located along the above-mentioned 2-fold axis about $2.97 \AA$ from the six-atom plane. The Fe-P distances are approximately equal (2.206 (2) and $2.216(2) \AA$ ) and the angle $\mathrm{P}(1)-\mathrm{Fe}-\mathrm{P}(2)$ is $177.78(9)^{\circ}$. Other structural parameters for the ligands are in the expected range for distances and angles involving $\mathrm{P}$ or $\mathrm{C}$ atoms.

The X-ray structure of 2 as shown in Figure 2 reveals a trigonalbipyramidal $\mathrm{Fe}(0)$ complex with the chelating diphosphine occupying one axial and one equatorial sites, corresponding to a cis form. Because of the five carbon chain between two phosphine moieties, 2 has an eight-membered chelate ring and a distorted trigonal-bipyramidal geometry around the $\mathrm{Fe}(0)$ center. The $P(1)-F e-P(2)$ angle is $97.1(1)^{\circ}$, which is larger than the corresponding angles in (dppm) $\mathrm{Fe}(\mathrm{CO})_{3}, 73.5(1)^{\circ}, 14$ (dppe). $\mathrm{Fe}(\mathrm{CO})_{3}, 84.1(1)^{\circ},{ }^{15}$ (dppp) Fe $(\mathrm{CO})_{3}, 91.5(7)^{\circ}, 16$ and (dppb)$\mathrm{Fe}(\mathrm{CO})_{3}, 92.4(1)^{\circ}, 16$ corresponding to the increase in the carbon chain length of the diphosphine. The axis of the tbp is along $\mathrm{P}(2)-\mathrm{Fe}-\mathrm{C}(1)$ with an angle of $171.8(4)^{\circ}$. The bond distances and angles about $P$ and $C$ are similar to those in similar (diphosphine) $\mathrm{Fe}(\mathrm{CO})_{3}$ structures. The axial $\mathrm{Fe}-\mathrm{C}(1)$ length, 1.657 (14) $\AA$, is much shorter than other $\mathrm{Fe}-\mathrm{C}$ lengths ranging $1.74-1.78$ 
Table III. Final Atomic Fractional Coordinates and Equivalent Isotropic Displacement Coefficients $\left(\mathrm{A}^{2}\right)$ for (dppt) $\mathrm{Fe}(\mathrm{CO})_{3}(2)$

\begin{tabular}{|c|c|c|c|c|}
\hline atom & $x$ & $y$ & $z$ & $B_{\text {iso }}^{a}$ \\
\hline $\mathrm{Fe}$ & 0.03934 & $0.23257(12)$ & 0.33927 & $2.85(7)$ \\
\hline $\mathbf{P}(1)$ & 0.04078 & $0.34159(25)$ & $0.21715(25)$ & $2.84(13)$ \\
\hline $\mathrm{P}(2)$ & $-0.07657(16)$ & $0.30304(24)$ & $0.32643(25)$ & $2.75(12)$ \\
\hline$O(1)$ & $0.1904(6)$ & $0.1239(10)$ & $0.3858(6)$ & $7.1(6)$ \\
\hline$O(2)$ & $-0.0227(6)$ & $-0.0246(8)$ & $0.2979(7)$ & $6.6(6)$ \\
\hline$O(3)$ & $0.1098(6)$ & $0.3484(9)$ & $0.5241(6)$ & $7.0(6)$ \\
\hline$C(1)$ & $0.1265(7)$ & 0.1743 (13) & $0.3639(8)$ & $4.8(7)$ \\
\hline$C(2)$ & $-0.0004(7)$ & $0.0814(10)$ & $0.3125(8)$ & $4.1(6)$ \\
\hline$C(3)$ & $0.0806(6)$ & $0.3084(10)$ & $0.4492(9)$ & $4.2(6)$ \\
\hline$C(4)$ & $0.0942(5)$ & $0.4947(10)$ & $0.2527(7)$ & $3.2(5)$ \\
\hline$C(5)$ & $0.1695(7)$ & $0.4908(11)$ & $0.3180(8)$ & $4.3(6)$ \\
\hline$C(6)$ & $0.2103(7)$ & 0.6033 (14) & $0.3523(8)$ & $5.3(7)$ \\
\hline$C(7)$ & $0.1756(8)$ & 0.7185 (12) & $0.3183(10)$ & $5.2(8)$ \\
\hline$C(8)$ & $0.1008(7)$ & 0.7225 (11) & $0.2550(10)$ & $5.1(7)$ \\
\hline C(9) & $0.0609(6)$ & 0.6110 (11) & $0.2205(8)$ & $4.5(6)$ \\
\hline$C(10)$ & $0.0889(6)$ & 0.2609 (11) & $0.1516(7)$ & $3.4(5)$ \\
\hline C(11) & $0.0877(6)$ & 0.1301 (11) & $0.1446(8)$ & $4.3(6)$ \\
\hline$C(12)$ & $0.1166(8)$ & $0.0682(13)$ & $0.0878(9)$ & $5.5(7)$ \\
\hline$C(13)$ & $0.1480(7)$ & 0.1391 (17) & $0.0390(9)$ & $6.1(8)$ \\
\hline$C(14)$ & $0.1495(7)$ & $0.2717(15)$ & $0.0463(9)$ & $5.4(8)$ \\
\hline$C(15)$ & $0.1208(7)$ & $0.3321(12)$ & $0.1021(8)$ & $4.4(6)$ \\
\hline$C(16)$ & $-0.0481(6)$ & $0.3927(10)$ & $0.1186(7)$ & $3.6(5)$ \\
\hline $\mathrm{C}(17)$ & $-0.0983(6)$ & $0.2874(12)$ & $0.0559(8)$ & $4.7(6)$ \\
\hline$C(18)$ & $-0.1402(7)$ & $0.2011(12)$ & $0.0930(9)$ & $5.2(7)$ \\
\hline$C(19)$ & $-0.1901(6)$ & $0.2639(12)$ & $0.1343(8)$ & $4.6(6)$ \\
\hline$C(20)$ & $-0.1661(6)$ & 0.2313 (11) & $0.2381(7)$ & $3.8(5)$ \\
\hline$C(21)$ & $-0.0973(6)$ & $0.4759(9)$ & $0.3146(7)$ & $2.9(5)$ \\
\hline$C(22)$ & $-0.0356(6)$ & $0.5613(10)$ & $0.3532(7)$ & $3.7(5)$ \\
\hline$C(23)$ & $-0.0508(7)$ & $0.6907(10)$ & $0.3524(8)$ & $3.9(6)$ \\
\hline$C(24)$ & $-0.1250(7)$ & $0.7356(10)$ & $0.3132(8)$ & $4.0(6)$ \\
\hline$C(25)$ & $-0.1866(7)$ & 0.6533 (11) & $0.2723(8)$ & $4.2(6)$ \\
\hline$C(26)$ & $-0.1734(6)$ & $0.5233(11)$ & $0.2723(7)$ & $4.1(6)$ \\
\hline$C(27)$ & $-0.0926(6)$ & $0.2661(10)$ & $0.4310(7)$ & $3.1(5)$ \\
\hline $\mathrm{C}(28)$ & $-0.0611(7)$ & 0.1501 (11) & $0.4791(9)$ & $4.9(7)$ \\
\hline C(29) & $-0.0768(7)$ & $0.1175(12)$ & $0.5542(8)$ & $5.1(7)$ \\
\hline$C(30)$ & $-0.1192(7)$ & $0.1934(13)$ & $0.5846(8)$ & $4.9(7)$ \\
\hline$C(31)$ & $-0.1482(7)$ & $0.3072(12)$ & $0.5404(8)$ & $4.8(7)$ \\
\hline$C(32)$ & $-0.1339(6)$ & $0.3432(10)$ & $0.4639(7)$ & $3.5(5)$ \\
\hline
\end{tabular}

$\AA$. The reason for the shortening may be due to a steric effect derived from elongating the carbon chain of the diphosphine. The major difference between the two synthetic routes is the
Scheme I

$$
\begin{aligned}
& (\mathrm{MA}) \mathrm{Fe}(\mathrm{CO})_{4} \frac{\mathrm{THF}, 0^{\circ} \mathrm{C}}{\mathrm{Me}_{3} \mathrm{NO}, \cdot \mathrm{CO}_{2}}\left[(\mathrm{MA}) \mathrm{Fe}(\mathrm{CO})_{3}\left(\mathrm{NM}_{3}\right)\right] \frac{\mathrm{dppt}, \mathrm{THF}, 70^{\circ} \mathrm{C}}{-\left(\mathrm{HNMe}_{3}\right)^{+}(\mathrm{MA})^{-}} \\
& \text {( } \\
& 1
\end{aligned}
$$

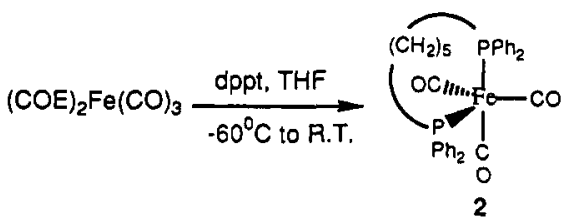

difference in temperature. Since dimeric 1 is produced at a much higher temperature than monomeric 2,1 is likely the thermodynamically more stable form whereas 2 may simply be a kinetic product. To test whether 2 converts to 1 at high temperature, the THF solution of 2 was heated at reflux and monitored periodically with IR spectroscopy. The IR $v_{\text {co }}$ single-band pattern of dimeric 1 is totally different from the three-band pattern of monomeric 2. Yet the THF solution has not shown any significant change in IR $\nu_{\text {CO }}$ band pattern over 2 days. Final mixtures have been worked-up, too, and subjected to ${ }^{3} \mathrm{P}\left\{{ }^{1} \mathrm{H}\right\}$ NMR studies, which exhibit some paramagnetic species but not dimeric 1. Apparently, monomeric 2 in refluxing THF proceeds with reaction pathways other than transformation to 1 .

Acknowledgment. The partial financial support from the National Science Council, ROC, is acknowledged. We thank Mr. Yuh-Sheng Wen for assistance with the single-crystal X-ray diffraction data collection. We also thank Ms. Li-Hong Tseng for measurement of ${ }^{31} \mathrm{P}\left\{{ }^{1} \mathrm{H}\right\}$ NMR spectra.

Supplementary Material Available: For the structures of 1 and 2, listings of crystallographic data, positional and anisotropic thermal parameters, and bond distances and angles (11 pages). Ordering information is given on any current masthead page. 